Témoigner Témoigner. Entre histoire et mémoire

Getuigen Revue pluridisciplinaire de la Fondation Auschwitz

Violences radicales en scène

\title{
Michelle Caswell. Archiving the Unspeakable. Silence, Memory, and the Photographic Record in Cambodia
}

University of Wisconsin Press, 2014

\section{Sayma Khan}

\section{OpenEdition}

\section{Journals}

Electronic version

URL: https://journals.openedition.org/temoigner/3683

DOI: $10.4000 /$ temoigner.3683

ISSN: 2506-6390

Publisher:

Éditions du Centre d'études et de documentation Mémoire d'Auschwitz, Éditions Kimé

\section{Printed version}

Date of publication: 1 October 2015

Number of pages: 205-206

ISSN: 2031-4183

\section{Electronic reference}

Sayma Khan, "Michelle Caswell. Archiving the Unspeakable. Silence, Memory, and the Photographic Record in Cambodia", Témoigner. Entre histoire et mémoire [Online], 121 | 2015, Online since 01 October 2016, connection on 04 February 2022. URL: http://journals.openedition.org/temoigner/3683 ; DOI: https://doi.org/10.4000/temoigner.3683

This text was automatically generated on 4 February 2022.

Tous droits réservés 


\section{Michelle Caswell. Archiving the Unspeakable. Silence, Memory, and the Photographic Record in Cambodia}

University of Wisconsin Press, 2014

\section{Sayma Khan}

\section{REFERENCES}

Michelle Caswell. Archiving the Unspeakable. Silence, Memory, and the Photographic Record in Cambodia. University of Wisconsin Press, 2014, 246 p.

1 Looking back at the twentieth century one cannot be ignorant of or remain unperturbed by the miscellaneous cases of human suffering in the forms of mass murder, genocide and ethnic cleansing (including the examples of the Holocaust, the Rwanda genocide, mass killings during the South Asian Partition, the Cambodian genocide, and the Armenian genocide, to name but a few). In the aftermath of genocide both collective remembrance and collective amnesia prevailed in different contexts to deal with a traumatic past. However, since the turn of the millennium, international politics as well as national endeavours seem to rigorously deliberate on and foreground aspects of justice and reconciliation - primarily through judiciary measurements. Archiving the Unspeakable. Silence, Memory, and the Photographic Record in Cambodia by Michelle Caswell makes an attempt to show how photographs, or rather mug shots taken of the prisoners at the Tuol sleng before their execution by the Cambodian Khmer Rouge regime (1975-1979), serve as "documentary evidence and visual aids that prompt survivors to give narrative testimony about their experiences during the Khmer Rouge regime" (9).

2 The mug shots - originally a part of the Khmer Rouge archive - reveal a performative agency and a distinctive social life, especially by virtue of reactivations by various groups of people in the present (i.e. Khmer Rouge survivors, family members of the 
victims, human rights activists, government officials amongst others). The photographs are indeed taken out of their original context and laden with multiple meanings with the passage of time by different agents, which show the potential of archival revivification and the way mnemonic practices occurring in the present help in reshaping the past. The original function of the mug shots embedded in the bureaucratic system of the Khmer Rouge regime that created the pictures in order to transform the "suspects depicted in them into criminals" and to facilitate a separation of "administrative order to kill from actual violence" (48), is vital here, since these acts made the mug shots into special forms of documentation through which the criminals could be legitimately created in the first place. The camera hereby gained an agency, a power that "produced the truth it recorded" (51). With the end of the regime, the mug shots came under control of the new government, which then used them to uncover the atrocities of the Khmer Rouge; Tuol Sleng mug shots, once an apparatus to legitimize the terror of the Khmer Rouge, quickly turned into an apparatus that was used to delegitimize that same regime.

Despite the continuous reactivations of the Khmer Rouge mug shots for various purposes in the past decades, a significant question raised by Caswell in her book concerns the "silence" that surrounds these photographs - a silence that particularly pertains to the victims who were not photographed or recorded, whose records were not archived, or the ones that were not deployable due to their destruction. Therefore, the mug shots displayed at museums or used at the tribunals as evidence can simultaneously be regarded as "a presence and an absence" (22) - reminding us both of the victims who are depicted and those who are not. The representation of this presence/absence and the (hidden) narratives in the Tuol sleng mug shots is negotiated in the four chapters of the book that subsequently trace the making of records, archives, narratives and commodities. The silencing of the victims and the retrieval of their voices today through active attempts by survivors, family members of the victims, archivists alike, is the underlining theme of the book. It is due to the remediation of the mug shots across the past decades that awareness was raised of the atrocities committed by the Khmer Rouge, evidence provided in legal cases against the regime. With the help of DC-Cam - originally "a field office at Yale and later an independent Cambodian run nongovernmental organization" (77) - Tuol sleng records were digitized and microfilmed. Today, the mug shotsare part of the Tuol Sleng genocide museum in Cambodia where they bear witness to an atrocious past. They also appear as symbols of remembering in a series of documentaries, stimulating the production of testimonial narratives with family members of the deceased. The initial silence of the victims is thus counteracted and memories of the deceased unearthed.

What the breaking of silence through multiple usages of the mug shots implies for us, the spectators, is a pertinent question that runs through the book. By looking at the pictures and listening to the narratives of survivors and family members of the victims, we acquire the role of witnesses. Caswell poignantly states how the "deployment of the Khmer Rouge records for the creation of narratives [induces] victims' family members [...] from silence into testimony" (132), and turns them into secondary witnesses and the listeners and viewers into tertiary witnesses, imposing an ethical imperative to see and listen to the (silenced) victims. Seen in this manner, the significance of the mug shots is not to be conceived as final of fixed. Rather, their meaning is always in the "process of becoming" (133), and every re-activation of the pictures necessitates a recontextualization of their semantic and social value. Archiving the Unspeakable is a 
worthy attempt to foreground the importance of archives by revealing the layers of silences associated with the mug shots of the Tuol sleng victims and demonstrating how their re-usages contribute to the disclosing of lost narratives.

\section{AUTHORS}

\section{SAYMA KHAN}

Goethe University Frankfurt 